\title{
The effects of sound pollution as a stress factor for the Baikal coregonid fish
}

\author{
Sapozhnikova Yu.P. ${ }^{1, *}$, Gasarov P.V. ${ }^{2}$, Makarov M.M. ${ }^{1}$, Kulikov V.A. ${ }^{3,4}$, \\ Yakhnenko V.M. ${ }^{1}$, Glyzina O.Yu. ${ }^{1}$, Tyagun M.L. ${ }^{1}$, Belkova N.L. ${ }^{\circledR}{ }^{\oplus}$, Wanzenböck Jo. ${ }^{5}$, \\ Sullip M.K. ${ }^{6}$, Sukhanova L.V. ${ }^{1}$ \\ ${ }^{1}$ Limnological Institute, Siberian Branch of the Russian Academy of Sciences, Ulan-Batorskaya Str., 3, Irkutsk, 664033, Russia \\ ${ }^{2}$ Irkutsk State University, Irkutsk 664003, Russia \\ ${ }^{3}$ Skolkovo Institute of Science and Technology, Moscow 143026, Russia \\ ${ }^{4}$ Institute of Automation and Electrometry, Siberian Branch of the Russian Academy of Sciences, Novosibirsk 630090, Russia \\ ${ }^{5}$ Research Institute for Limnology Mondsee, University of Innsbruck, A-5310 Mondsee, Austria \\ ${ }^{6}$ ICAR-National Bureau of Fish Genetic Resources, Telibagh, Lucknow 226 002, India
}

\begin{abstract}
We have studied morphological features of the hearing epithelium affected and unaffected by increased long-term sound (at $160 \mathrm{~dB}$ re $1 \mu \mathrm{Pa}$ ) on the example of the Baikal omul (Coregonidae, Coregonus migratorius). The sensory epithelium was analyzed using the 3D confocal laser scanning techniques. We observed local epithelium damages in the rostral, central and caudal regions of the saccule, e.g. sticking stereocilia, vacuolization and round shape gaps. This article discusses the reasons for the local effects of sound on different regions of the sensory epithelium. We assume that using of morphological screening of sensory acoustic system in the artificial rearing of the Baikal coregonid fishes under the conditions of intense noise could contribute to indicating the most stress-resistant forms, which are promising for high-tech industrial aquaculture, and developing more gentle approaches to its creation.
\end{abstract}

Keywords: Lake Baikal, sound as a stress factor, hair cells, sensory epithelium, Baikal omul

\section{Introduction}

The study of fish hearing and their acoustic behavior is important due to increasing effects of sound pollution on fish in their natural habitat (Hastings et al., 1996; Popper and Hastings, 2009; Ladich, 2013; Sapozhnikova, 2018). Intensive production of fish in aquaculture also involves the use of equipment, such as aerators, air and water pumps, combines, blowers, and filtration systems, which increase the noise level in fish storage tanks (Wysocki et al., 2007). Constant exposure to intense noise levels can adversely affect the cultivated species. Possible consequences include impairment of hearing sensitivity, increased stress, and reduced growth rates (Popper and Hastings, 2009). As a result, the acoustic conditions of larvae maintaining during artificial reproduction of fish populations determine their further survival and population replenishment. After their release into the wildlife, they use their sensory organs in order to locate direction, select suitable habitat, settle at locations with sufficient shelter, and avoid the immediate attention of many voracious predators (Montgomery et al., 2006; Caiger et al., 2012).
Fish estimate the locomotion of their body in the acoustic field relative to the otoliths in the inner ears, the utricle, saccule, and lagena (Popper, 2011; Ladich and Schulz-Mirbach, 2016). Nevertheless, the saccule has the main auditory load in many fishes (Zhongmin and $\mathrm{Xu}, 2002$ ). Sagitta is usually larger than other parts of the labyrinths in these fishes; the removal of both sagittae sharply reduces the auditory sensitivity ( $\mathrm{Lu}$ and $\mathrm{Xu}, 2002)$. These results demonstrate that the saccule plays significant roles in hearing and frequency distinction. In addition, the largest diversity in ultrastructural features for teleosts is characteristic of the saccule (Platt and Popper, 1981; Popper and Coombs, 1982; Popper and Fay, 1999; Sapozhnikova et al., 2017).

The saccular otoliths lag in their locomotion relative to the fish body in the acoustic field and thus stimulate the sensory saccular cells by deflecting their ciliary (hair) bundles (Fig. 1). This mediated process limits the detectable frequencies to a few hundred hertz and restricts the sound intensities to higher levels (Schuijf and Hawkins, 1976; Bradbury and Vehrencamp, 2011).

Lake Baikal was previously suggested as an ideal location for investigation of the application of ocean sound propagation models and assessment of

*Corresponding author.

E-mail address: jsap@mail.ru (Yu.P. Sapozhnikova) 


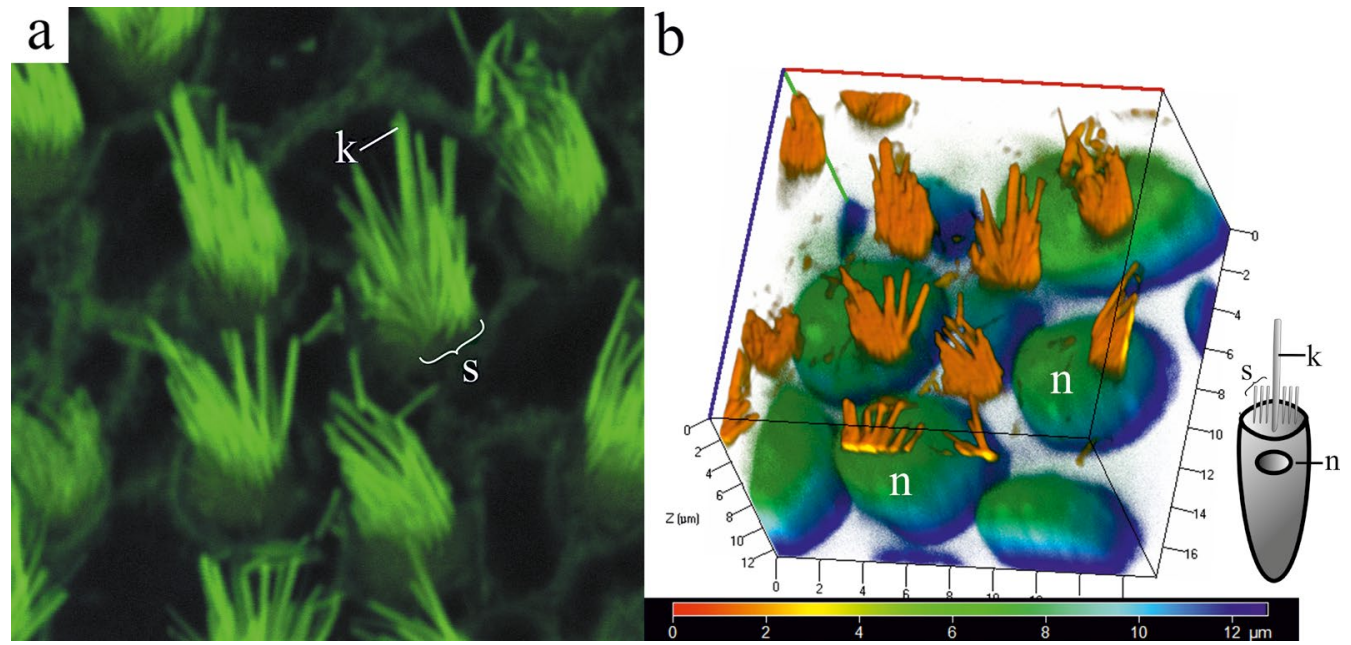

Fig. 1. Sensory epithelium of the Baikal omul (LSM 710, Carl Zeiss): a - sensory elements on the surface of the epithelium; $\mathrm{b}-3 \mathrm{D}$ model of sensory epithelium. $\mathrm{k}$ - kinocilium, $\mathrm{s}-$ stereocilia, $\mathrm{n}$ - nucleus.

hearing adaptations in hydrobionts (Glotin et al., 2017). Although some sounds are natural for Lake Baikal (ice crackle, natural gas seepages, surf noise in the splash zone, voices of seals and birds), now, there is often a cacophony of transient and continuous man-made sound from boating, shipping, construction, nearby roadways, tunnels, etc. Thus, another question is whether these sounds potentially interfere with the behavior of fish populations. The greatest effect may result from acoustic masking which would shorten the distances over which animals can detect sounds of biological importance, for example, from potential predators (Engas et al., 1996; Hawkins et al., 2014; Hughes et al., 2014; Voellmy et al., 2014; Glotin et al., 2017).

The fish with high hearing characterstics may be affected by this noise up to a distance of several hundred meters (Amoser et al., 2004; Ladich, 2013), but fish lacking hearing characterstics, such as lacustrine and riverine coregonid fishes, would be affected predominantly at close distance, which is also typical for aquaculture cultivation.

Among Baikal coregonid fishes, omul is more popular for growing in aquaculture, particularly due to the reduction of its populations in the natural conditions and the introduction of a ban on its catch in 2017 for Lake Baikal. Omul is one of the most important species to the subsistence fisheries throughout the world, including Lake Baikal (Tallman and Reist, 1997; Smirnov et al., 2009; Sukhanova et al., 2017).

Therefore, this study was aimed at the evaluation of long-term effects of increased sound on the auditory epithelium of the Baikal omul. In previous studies, control hearing thresholds showed that coregonid fishes (on the example of broad whitefish Coregonus nasus Pallas, 1776) had far less sensitive hearing and broader bandwidth of hearing than other investigated fish (Popper et al., 2005). This was expected, since the coregonid fish is not a member of the superorder Otophysi, a group of hearing specialists that have a set of bones, the Weberian ossicles, which acoustically couple the swim bladder to the saccule of the inner ear. The initial analysis of hearing sensitivity in coregonid fish showed that they could detect sounds up to $1600 \mathrm{~Hz}$ (Popper et al., 2005). However, they have a very poor hearing at $1600 \mathrm{~Hz}$. Therefore, in our work the specimens were exposed to the 500 and $1 \mathrm{kHz}$ tones at $160 \mathrm{~dB}$ re $1 \mu \mathrm{Pa}$, which are within the range of hearing of this species and are usually observed in artificial cultivation.

\section{Materials and methods}

The study objects were adult specimens of the artificially obtained Baikal omul (Coregonidae, Coregonus migratorius). Coregonid fishes was artificially inseminated under controlled conditions of the Unique Facility «Experimental Freshwater Aquarium Complex of Baikal Hydrobionts» at the Limnological Institute Siberian Branch of the Russian Academy of Sciences.

To conduct the evaluation experiments of the effects of increased sound on the auditory organs of the Baikal fish under the conditions of the Aquarium Complex, the installation consisting of two round pools with a diameter of $2 \mathrm{~m}$ and a height of $0.5 \mathrm{~m}$ was constructed. These two pools were located in separate rooms. One pool had the control fish (without the sound stimulation) and another one had sound-exposed fish (an experimental pool). In both pools, fish were maintained with daily 50\% water changes. The walls of the pools were made of plastic.

Tone signals with the frequencies of $500 \mathrm{~Hz}$ and $1 \mathrm{kHz}$ (corresponding to determined ranges of acoustic sensitivity) at $160 \mathrm{~dB}$ re $1 \mu \mathrm{Pa}$ were generated through a portable computer using the Sound Forge program (Fig. 2). The sound was radiated continuously for 18 days in the experimental pool. After the amplifier, the signal was fed to the UW30 Electro-Voice hydroacoustic emitter with operating frequencies of $100 \mathrm{~Hz}-100 \mathrm{kHz}$ and nameplate capacity of $120 \mathrm{~W}$. The emitter was set under the water at half the depth of the experimental pool for noise-exposed fish. The form and intensity of the emitted signal were controlled using the RESON TC 4013 piezoceramic transducers. After the linear amplifier, the signal from the transducer was fed to the LCard E-440D analog-digital converter. The amplitude and frequency analysis were carried out using the specialized LCard PowerGraph software. The sensitivity of fish to the sound signal was determined visually and 

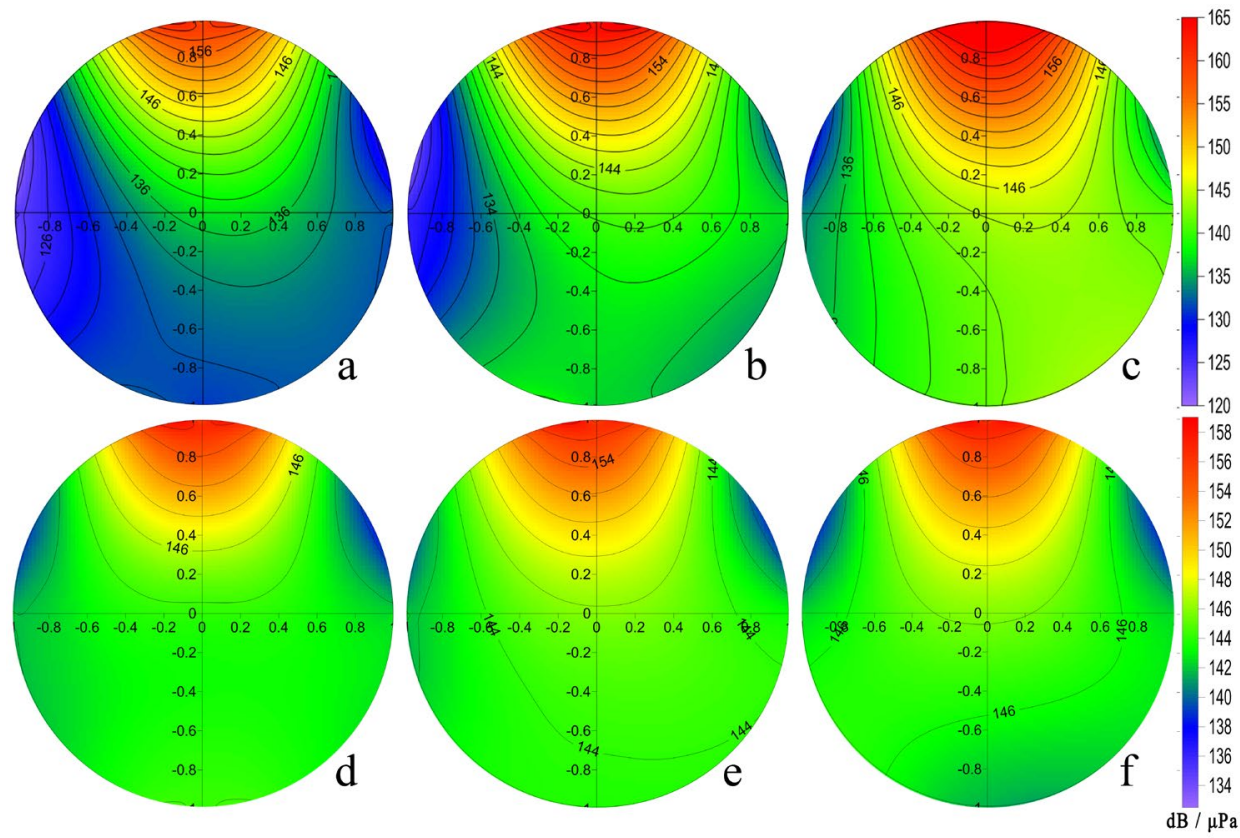

Fig. 2. Uneven sound field of $500 \mathrm{~Hz}(\mathrm{a}, \mathrm{b}, \mathrm{c})$ and $1 \mathrm{kHz}(\mathrm{d}, \mathrm{e}, \mathrm{f})$ in the horizontal plane, scale in $\mathrm{dB} / \mu \mathrm{Pa}$ : a, $\mathrm{d}-\mathrm{the}$ surface, $\mathrm{b}, \mathrm{e}-$ half the depth, and c, f - the bottom.

by the EthoStudio density maps, as well as by activity of the specimens and a positive reaction to a certain acoustic signal (active movements and jerks) (Kulikov et al., 2014).

Fish from both experimental and control pools were collected with a dip-net, euthanized by using clove oil (0.02-0.05 $\mathrm{ml} / 1$, a sedative, contains eugenol) and killed by cutting the spine in accordance with Guidance on the use of clove oil as an anesthetic in aquaculture (Mikodina et al., 2011) and the American Veterinary Medical Association (AVMA) Guidelines for Euthanasia (2013).

Immediately prior to the preparation of the auditory organ samples, the cranium was opened from the ventral side, the brain was removed, the ear capsules were uncovered, the right and left labyrinths were extracted, and the saccule was removed together with the sagitta (otolith). Hair cell bundle loss was determined using laser confocal scanning microscopy LSM 710 (Carl Zeiss).

Histological processing of the samples with sensory epithelium was performed according to the standard technique (Klimenkov et al., 2018). The sensory epithelium was fixed for $30 \mathrm{~min}$ in a $2 \%$ paraformaldehyde (Sigma-Aldrich Co. LLC, USA, Cat. No. 158127) solution in $0.1 \mathrm{M}$ phosphate buffer $(\mathrm{pH} 7.4)$ and permeabilized for 20 min in $0.25 \%$ Triton $^{\mathrm{TM}} \mathrm{X}-100$ (SigmaAldrich Co. LLC, USA, Cat. No. T8787). Actin microfilaments were stained for 40 min with FITC-Phalloidin (Sigma-Aldrich Co. LLC, USA, Cat. No. P5282). The nuclei were stained for 15 min with DAPI (SigmaAldrich Co. LLC, USA, Cat. No. D9542). Functionally active mitochondria were stained with MitoTracker ${ }^{\circledR}$ Orange CMTMRos (Termo Fisher Scientifc Inc., USA, Cat. No. M7510) by 25-min incubation in medium 199 with Hank's salts (Kompaniya PanEko, Russia, Cat. No. S230p); the medium contained 100-500 nM dye at 37 ${ }^{\circ} \mathrm{C}$. After each step, the samples were washed three times in Hank's solution without phenol red (PanEko, Russia,
Cat. No P020p). The stained samples were mounted on glass slides in ProLong ${ }^{\circledR}$ Gold Antifade Mountant (Termo Fisher Scientifc Inc., USA, Cat. No. P36930) and covered with a coverslip. The slides were analyzed using a Carl Zeiss LSM 710 laser confocal microscope; Plan-Apochromat $20 \times / 0.8$ and $63 \times / 1.40$ Oil DIC M27; lasers: track 1, $405 \mathrm{~nm}$ : 3.0\%; track 2, $488 \mathrm{~nm}$ : 3.0\%; track 3, $561 \mathrm{~nm}: 3.0 \%$.

The morphometric analysis yielded 10-50 images of each macula along the length and depth (depending on the length of the epithelium) at an interval of 30 $\mu \mathrm{m}$. The density of hair cells on the macula, the length of sensory elements (kinocilium and stereocilia) and hair cell bundle loss were measured using program Image-Pro Plus.

To classify hair cells, cluster analysis was used, in particular, k-means and hierarchical clustering, using the Statistica 8.0 program. Quantitative similarity indicator of hair cells belonging to the same cluster was calculated from the lengths of the kinocilia $(\mathrm{k})$ and the maximum length of the stereocilia (s). Statistical processing of the obtained data was carried out using the single-factor analysis of variance in the $\mathrm{R}$ Project. The Kruskal-Wallis test was used for the verification of the null hypothesis.

\section{Results and discussion}

Confocal scanning microscopy revealed regional distinctions in native hair cells of fish based on the different density of hair cells in central and caudal regions of the epithelium, as well as the presence of different types of cells in these regions. The mean density of the intact hair cells in the rostral region was $571500 \pm 8975$ cells $/ \mathrm{mm} 2, \mathrm{M} \pm \mathrm{m}$ in the Baikal omul. In the central region of the macula, hair cells were considerably distant from each other. The hair cells of the caudal region were located more densely. 

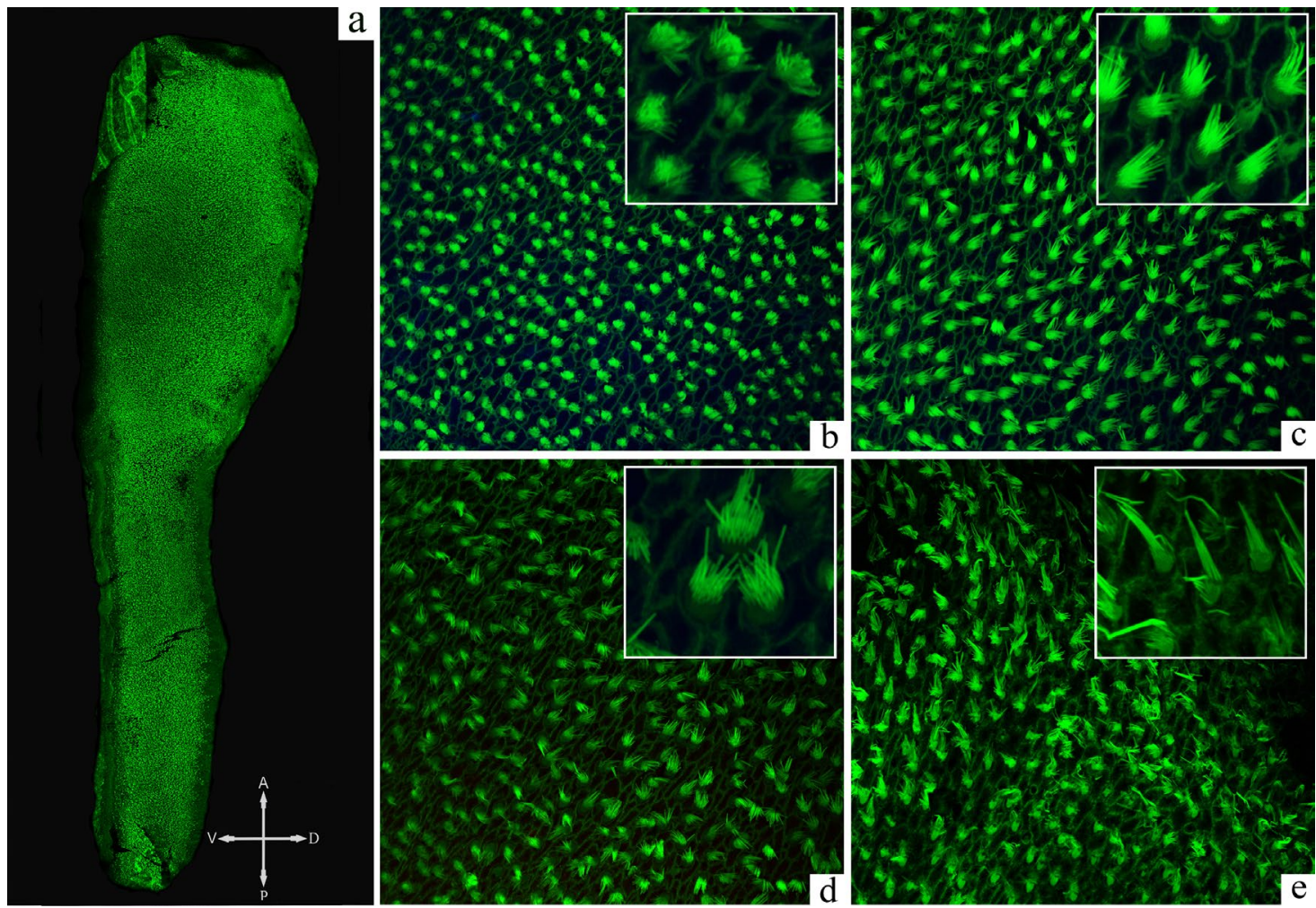

Fig. 3. Different types of the sensory saccular cells in Baikal omul: a - general view of the saccule; $b-k 3 s 2$ type; $c-k 6 s 5$ type; d - k7s2 type; e - k11s4 type. k - kinocilium, s - stereocilia. Orientation of the saccule: V - ventral, D - dorsal, A - anterior (rostral), $\mathrm{P}$ - posterior (caudal). LSM 710, Carl Zeiss.

Cluster analysis combined sensory cells into classes (types) in such a way that similar cells were included in one class. The length of kinocilium $(\mathrm{k})$ and maximum length for stereocilium in one sensory bundle (s) were the most significant characteristics for the integration of sensory cells into different clusters (designation for cilia was used by Platt and Popper (1981)). These most variable characteristics were regarded as criteria for identification of types of sensory saccular cells. Four cell morphotypes were identified in the Baikal omul, k3s2, k6s5, k7s2, and k11s4 (Fig. 3).

These hair cell types vary across the peripheral, rostral, central and caudal areas of the saccule. The cell types k3s2, k6s5, k7s2, and k11s4 were the most typical for the peripheral and caudal areas of the saccule. The type k7s2 was found in the rostral region of the saccule. Finally, in the central region of the saccule, we identified the cell types k3s2 and k7s2. Thus, in the Baikal omul cells, stereociliar and kinociliar length varies by location: shorter stereocilia are more characteristic of the central and rostral regions of the saccule, longer stereocilia were found in the peripheral and caudal regions of the saccule.

In the course of the experiment on the increased acoustic stimulation of the Baikal omul, there were no exposure effects on mortality. The swim bladders were intact in all experimental and control specimens. But after confocal scanning of sensory hearing epithelium, we found varieties of local epithelial damages: rounded ruptures emerging on the surface of the epithelium, the coalescence of stereocilia described previously for other animals damaged by highly intense sound or ototoxic antibiotics (Wysocki et al., 2007). Damage of various parts of the sensory epithelium of the inner ear occurs unevenly. The hair cell bundle loss in the Baikal omul was individual and varied in different parts of the rostral, central, and caudal regions, at the saccule of each fish. In some specimens, the damages are represented by small foci, in other ones significant areas were injured. However, there were some patterns: the damaged areas were localized and usually varied as a function of exposure sound frequency. The cell damages were minimal at $1 \mathrm{kHz}$. The small areas of damaged hair cells were observed throughout the epithelium, and, primarily, in the central and rostral areas.

Visible changes in the epithelium occurred only on the 10th day of the experiment at $500 \mathrm{~Hz}$, and then gradually depending on the day of stimulation: evident vacuolization was registered on the 10th day; obvious ruptures of the sensory epithelium were observed on the 18th day after the onset of sound stimulation (Fig. 4).

The zones of saccular hair cell loss were larger for fish exposed to $500 \mathrm{~Hz}$ (up to $44 \%$ in the different parts of the peripheral area on the 10th day after the onset of sound stimulation). This tone destroyed hair cells predominantly in the peripheral part with the largest cell injuries occurring in the caudal region (Fig. 4g-i). The destructive changes occurred in the hair cells on the 18th day after the onset of sound stimulation (up to $60 \%$ in the different parts of the peripheral area) (Fig. 4j-1). Thereby, there was a hypothesis about the tone selectivity in different areas of the auditory epithelium with the different cell types (Hawkins and Sand, 1977; Smith et al., 2011; Sapozhnikova et al., 2016). The changes in cells of the different saccular 

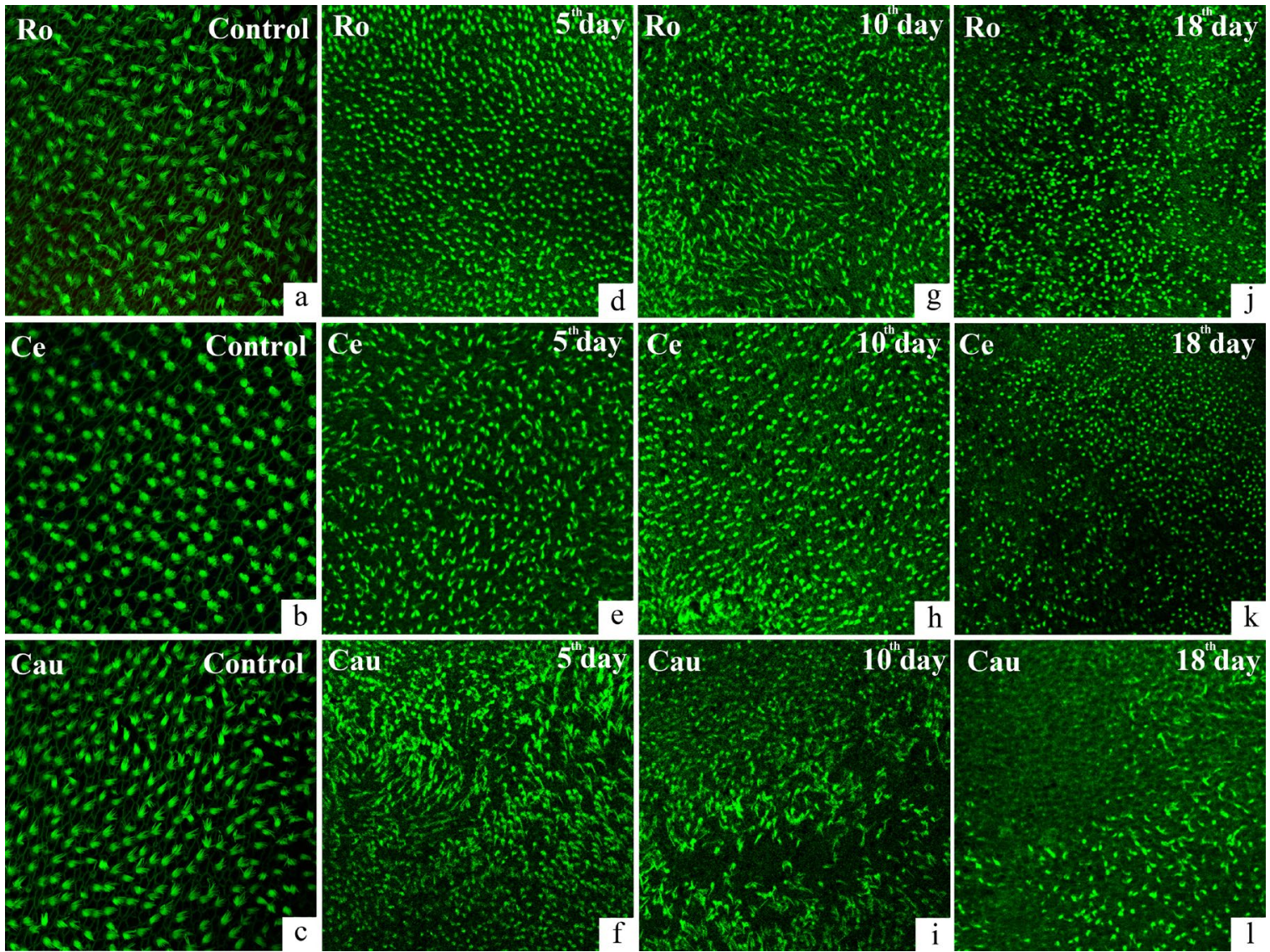

Fig. 4. Images obtained by LSM 710 (Carl Zeiss) showing hair cells destructive changes in the Baikal omul due to stimulation by increased sound $(500 \mathrm{~Hz}, 160 \mathrm{~dB}$ ) in rostral (Ro), central (Ce) and caudal (Cau) regions of the saccule: a-b - control; $\mathrm{d}$-f - epithelium after 5 days of sound exposure; $\mathrm{g}-\mathrm{i}$ - epithelium after 10 days of sound exposure; j-1 - epithelium after 18 days of sound exposure.

regions are likely to be a result of their damages due to the increased stimulation by various sounds, which confirms the involvement of these regions in the perception of relevant frequency sound oscillations.

\section{Conclusions}

The obtained results can be used for further study of the acoustic communication of the Baikal fishes, including conditions of acoustic pollution. Unfortunately, anthropogenic increased sound under natural conditions may dramatically reduce acoustic communication of fish reducing their ability to acoustically detect incoming hazards (Hastings et al., 1996; Popper and Hastings, 2009; Ladich, 2013). As it was previously shown, $50 \%$ of aquatic noise is generated by $15 \%$ of ships, and in some coastal and other hightraffic areas, ship noise has reached levels that degrade habitat for endangered species (Glotin et al., 2017). In particular, prolonged exposure to noise leads to stress, which may affect the nervous and immune systems of hydrobionts (Popper and Hastings, 2009).

The conducted experiment allows us to successfully record the response of specimens to the presence of sensitivity to a particular sound signal, including increased sound evoking anxiety. Moreover, the experiments, in which the increased acoustic stimulation caused a different degree of hair cell damages in different regions of the macula, presumably showed the existence of the regions with different tonal specia- lization in the auditory maculae of the Baikal omul. So far, we can make only preliminary conclusions about the presence of tonotopic specialization in different regions of the epithelium in coregonid fishes. However, a better understanding of the physiological processes causing cell damage and regeneration, which affect the behavior and lead to stress under the influence of different acoustic effects, requires additional studies. This work may be ultimately used to mitigate the effects of increased sounds on fish in aquaculture or in the natural environment, and contribute to the development of new approaches for the management of lake environment.

\section{Acknowledgements}

We are grateful to Yuliya Vitushenko (LIN SB RAS) for their valuable assistance in preparing the manuscript. Ethological and morphological screening of coregonid fish was performed at the LIN SB RAS Collective Instrumental Center (http://www.lin.irk.ru/ copp/eng/) using the Unique Facility «Experimental Freshwater Aquarium Complex of Baikal Hydrobionts» supported by RFBR and the Government of the Irkutsk Region, projects Nos. 17-44-388081 r_a and 17-44$388106 r_{-} a$, and within the framework of the State Task No. 0345-2016-0002 (AAAA-A16-116122110066-1) «Molecular Ecology and Evolution of Living Systems ...». Aquaculture of coregonid fish was obtained within the framework of the project of the Government of the 
Irkutsk Region «Obtaining a High-Tech Aquaculture of Whitefish ...» (Youth Forum Baikal-2020).

\section{References}

Amoser S., Wysocki L.E., Ladich F. 2004. Noise emission during the first powerboat race in an Alpine lake and potential impact on fish communities. Journal of the Acoustical Society of America 116: 3789-3797. DOI: 10.1121/1.1808219

Bradbury J.W., Vehrencamp S.L. 2011. Principles of animal communication. 2nd Edn. Sunderland: Sinauer Associates Inc. Publishers.

Caiger P.E., Montgomery Jo.C., Radford C.A. 2012. Chronic low-intensity noise exposure affects the hearing thresholds of juvenile snapper. Marine Ecology Progress Series 466: 225-232. DOI: 10.3354/meps09933

Engas A., Lokkeborg S., Ona E. et al. 1996. Effects of seismic shooting on local abundance and catch rates of cod (Gadus Morhua) and haddock (Melanogrammus aeglefinus). Canadian Journal of Fisheries and Aquatic Sciences 53: 22382249. DOI: $10.1139 /$ f96-177

Glotin H., Poupard M., Marxer R. et al. 2017. Big data passive acoustic for Baikal Lake soundscape and ecosystem observatory [B2O]. Toulon: DYNI CNRS LSIS team. (in Russian)

Hastings M.C., Popper A.N., Finneran J.J. et al. 1996. Effect of low frequency underwater sound on hair cells of the inner ear and lateral line of the teleost fish Astronotus ocellatus. Journal of the Acoustical Society of America 99: 17591766. DOI: $10.1121 / 1.414699$

Hawkins A.D., Sand O. 1977. Directional hearing in the median vertical plane by the cod. Journal of Comparative Physiology A 122: 1-8. DOI: 10.1007/BF00611244

Hawkins A., Roberts L., Cheesman S. 2014. Responses of free-living coastal pelagic fish to impulsive sounds. Journal of the Acoustical Society of America 135: 3101-3116. DOI: 10.1121/1.4870697

Hughes A.R., Mann D.A., Kimbro D.L. 2014. Predatory fish sounds can alter crab foraging behavior and influence bivalve abundance. Proceedings of the Royal Society B 281 . DOI: $10.1098 /$ rspb.2014.0715

Klimenkov I.V., Sudakov N.P., Pastukhov M.V. et al. 2018. Rearrangement of actin microfilaments in the development of olfactory receptor cells in fish. Scientific Reports 8. DOI: 0.1038/s41598-018-22049-7

Kulikov V.A., Sapozhnikova Yu.P., Kirilchik S.V. et al. 2014. Algorithms for quantitative analysis of the behavior of the Baikal omul under experimental conditions. In: V All-Russian Conference Fish Behavior, pp. 131-136. (in Russian)

Ladich F. 2013. Effects of noise on sound detection and acoustic communication in fishes. In: Brumm H. (Ed.), Animal communication and noise. Berlin: Springer, pp. 65-90.

Ladich F., Schulz-Mirbach T. 2016. Diversity in fish auditory systems: one of the riddles of sensory biology. Frontiers in Ecology and Evolution 4. DOI: 10.3389/fevo.2016.00028

Lu Z., Xu Z. 2002. Effects of saccular otolith removal on hearing sensitivity of the sleeper goby (Dormitator latifrons). Journal of Comparative Physiology A 188: 595-602. DOI: 10.1007/s00359-002-0334-6

Mikodina E.V., Sedova M.A., Pyanova S.V. et al. 2011. Aquaculture. Issue 6. Guidance on the use of an anesthetic "clove oil" in aquaculture. Moscow: VNIRO Publishing House. (in Russian)

Montgomery J.C., Jeffs A.G., Simpson S.D. et al. 2006.
Sound as an orientation cue for the pelagic larvae of reef fishes and decapod crustaceans. Advances in Marine Biology 51: 143-196. DOI: 10.1016/S0065-2881(06)51003-X

Platt C., Popper A.N. 1981. Fine structure of the ear. Hearing and sound communication in fishes. New York: Springer-Verlag, pp. 3-38.

Popper A.N. 2011. Auditory system morphology. In: Farrell A.P. (Ed.), Encyclopedia of fish physiology: from genome to environment. Amsterdam: Academic Press, pp. 252-261.

Popper A.N., Coombs S. 1982. The morphology and evolution of the ear in actinopterygian fishes. American Zoologist 22: 138-143.

Popper A.N., Fay R.R. 1999. The auditory periphery in fishes. In: Fay R.R., Popper A.N. (Eds.), Comparative hearing: fish and amphibians. New York: Springer Verlag, pp. 43-100.

Popper A.N., Hastings M.C. 2009. The effects of anthropogenic sources of sound on fishes. Journal of Fish Biology 75: 455-489.DOI: 10.1111/j.1095-8649.2009.02319.

Popper A.N., Ramcharitar J., Campana S.E. 2005. Why Otoliths? Insights from inner ear physiology and fisheries biology. Marine and Freshwater Research 56: 497-504. DOI: 10.1071/MF04267

Sapozhnikova Yu.P. 2018. Fish hearing. Science First Hand 80: 80-91. (in Russian)

Sapozhnikova Yu.P., Belous A.A., Makarov M.M. et al. 2017. Ultrastructural correlates of acoustic sensitivity in Baikal coregonid fishes. Fundamental and Applied Limnology 189: 267-278. DOI: $10.1127 / \mathrm{fal} / 2017 / 0810$

Sapozhnikova Yu.P., Klimenkov I.V., Khanaev I.V. et al. 2016. Ultrastructure of saccular epithelium sensory cells of four sculpin species (Cottoidei) of Lake Baikal in relation to their way of life. Journal of Ichthyology 56: 289-297. DOI: 10.1134/S0032945216010136

Schuijf A., Hawkins A.D. 1976. Sound reception in fish. Amsterdam, Oxford, New York: Elsevier Scientific Publishing Company.

Smirnov V.V., Smirnova-Zalumi N.S., Sukhanova L.V. 2009. Microevolution of Baikal omul: Coregonus autumnalis migratorius (Georgi). Novosibirsk: Publishing House of the SB RAS. (in Russian)

Smith M.E., Schuck J.B., Gilley R.R. et al. 2011. Structural and functional effects of acoustic exposure in goldfish: evidence for tonotopy in the teleost saccule. BMC Neuroscience 12: 1-16. DOI: 10.1186/1471-2202-12-19

Sukhanova L., Politov D., Wanzenbock Jo. et al. 2017. Biology and management of Coregonid fishes. Fundamental and Applied Limnology 189: 177-179. DOI: 10.1127/ $\mathrm{fal} / 2017 / 1028$

Tallman R.F., Reist J.D. 1997. Information requirements for fishery management and overview of scientific approach. Canadian Technical Report of Fisheries and Aquatic Sciences 2193: 53-62.

Voellmy I.K., Purser J., Simpson S.D. et al. 2014. Increased noise levels have different impacts on the antipredator behavior of two sympatric fish species. PLoS ONE 9: e102946. DOI: 10.1371/journal.pone.0102946

Wysocki L.E., Davidson III J.W., Smith M.E. et al. 2007. Effects of aquaculture production noise on hearing, growth, and disease resistance of rainbow trout Oncorhynchus mykiss. Aquaculture 272: 687-697. DOI: 10.1016/j. aquaculture.2007.07.225

Zhongmin L., Xu Z. 2002. Effects of saccular otolith removal on hearing sensitivity of the sleeper goby (Dormitator latifrons). Journal of Comparative Physiology 188: 595-602. DOI: $10.1007 /$ s00359-002-0334-6 